\title{
Reporting Clinical Activity On Military Operations - Time For Some Standardisation
}

\author{
MCM Bricknell
}

This Journal has published a number of important papers that provide a snap shot of the overall clinical experience of the Army Medical Services during the early, warfighting, phase of Operation TELIC in Iraq (1-8). Overall, these papers are an important addition to the evidence base that illustrates the maxim 'disease and non-battle injury generate a greater workload for the medical services than battle trauma'. This Journal has also published evidence of this maxim from the campaigns in the Balkans (9) and Exercise SAIF SERREA in Oman $(10,11)$.

Since the Gulf War of 1991, all Western military medical services are being gradually re-engineered from the austere, surgically dominated systems of the Cold War to the multi-specialty, integrated systems required to support modern expeditionary military operations. As highlighted in a paper from the 1990s (12), we have a collective responsibility to produce a robust evidence base that supports this re-engineering.

Unfortunately, there has been an inconsistent approach between papers reporting clinical activity from overseas operations. This makes it difficult to aggregate this data through systematic review to provide the robust evidence base that can inform the further development of operational medical systems. It is unlikely that any single medical facility in a theatre of operations will have sight of the whole medical picture, and the variation in the number of headquarters and the rotation of headquarters during the life-time of an operation means that is unlikely that any single Commander Medical will have the whole longitudinal medical picture. Thus, the published medical literature will become a valuable and easily accessible part of the historical record (through PubMed). Therefore, it is vital that all papers reporting clinical activity from military operations are both factually and scientifically complete and valid. I suggest that there are 3 essential components to such reports; description of data sources, clinical activity reporting, and diagnostic coding. I will use examples from the papers cited to illustrate my case.

There are three common data sources for military medical papers: those collected personally (1-3) the admission and discharge record for a medical facility $(4,10,11)$ and medical reports and returns $(2,5)$. Datasets collected by individual clinicians will represent very short snapshots of the whole picture given the high turnover of clinical staff required to minimise skill fade as a result of time away from clinical practice. Thus, the last two are likely to be the main sources of data. There may be reasons why these sources do not provide a representative sample of the whole medical experience in a specific theatre. For example, Grainge and Heber's paper (4) is based on the admission records of all cases seen at the Field Hospital in Shaibah Air Base, Basra. Initially the field hospital in this location was acting as a Role 2 facility with the UK Role 3 capability being provided by a hospital at Camp Coyote in Kuwait and PCRS Argus at sea (using the most recent NATO definitions (13)). When the warfighting phase of the operation was complete, the balance of medical effort shifted to Shaibah and the hospital in Camp Coyote closed. Compare this with Roberts et al's paper (1) based on records from 202 Field Hospital that was initially established as the Role 3 facility in Camp Coyote and then the staff relieved the staff in 34 Field Hospital in Shaibah. Both papers are valuable but neither paper represents the whole clinical experience of physicians or intensivists on OP Telic. It would seem preferable to utilise data collected across a whole Theatre of Operations based on medical reports and returns $(2,5)$ but, unfortunately, the current system does not provide the detailed clinical information that allows interpretation of the data by specialties within a clinical facility. Thus, the whole military medical record will be based around a combination of papers describing clinical activity from individual facilities and papers summarising medical reports and returns for the whole medical force within an operational theatre.

The aggregation of historical records is one vital method of estimating the rate of casualties to be expected from the risk of exposure to health threats faced by this a military population. Casualties are usually divided into Battle Casualties (BC), Disease and Non-Battle Injury. BC are further divided into Killed in Action (KIA), Captured and Missing in Action (CMIA), Wounded in Action (WIA) and Psychological casualties. Nuclear, Biological and Chemical (NBC) are considered separately (1). As our military medical systems become more refined (and more 
expensive) we will need to be able to improve our medical planning to estimate demand for individual specialties and medical capabilities (such as laboratory diagnostic tests or CT scanning). These requirements mean that every effort must be made to determine the incidence of clinical activity contained in military medical operations. This requires a combination of the total numbers of clinical cases, an estimate of the population at risk and a discussion of this relationship over time. My paper reporting hospital activity for Ex SAIF SERREA (11) showed discrepancies between the PERSREP and AP3 methods of determining the overall number of troops in a Theatre. It is clearly important that the figure for overall number of troops is valid as this is the key denominator in the calculation of rates. Furthermore, the risk for an individual of receiving treatment in a particular medical facility may vary during the study period. For instance, in the examples cited above, the population at risk of admission to the Field Hospital in Shaibah or the population at risk of admission to 202 Field Hospital will have varied as a proportion of the overall UK military population at risk during the study period.

Most authors will wish to describe the variation of clinical activity over time (e.g. operational activity, time of year, variation in environmental temperature) and an estimate of the rate of clinical activity. This may often be presented as a time series graph. Ideally the aggregation of clinical papers from an operational theatre should produce (with appropriate statistical confidence intervals): the attendance rate at Role 1 (primary care), the referral or outpatient attendance rate at Role 2/3 (hospital), the admission rate (to Role 2/3), the return to unit rate (from medical units), the mortality rate and the rate of evacuation from theatre. Authors should be encouraged to discuss the factors that influence these various rates and measures that can reduce them as far as reasonably possible. It is these figures that help to provide the evidence base for the Casualty Estimate for the medical support requirement for future military operations.

Having described the overall clinical activity, authors will then wish to break this down by a clinical category. Many papers do this by clinical specialty $(1,4,10)$ but it is important that any such categorisation is reproducible and comparable between reports. The J95 system was introduced in 1996 into the Army to provide a reliable system for reporting primary care activity (12). This has a system of diagnostic coding based on ICD-10 (16) that has also proved effective in the secondary care environment $(9,11)$. This same system (called EPINATO) is the standard for medical reports and returns within the NATO environment (13). There would seem to be considerable value in authors using this as the baseline diagnostic coding system.

This Journal has an important role as the institutional memory for the practice of medicine within the military environment (17). I suggest that there would be value in disseminating guidance for authors and reviewers on the key components of papers that report clinical activity. I have described how the patient population of a clinical facility can vary during a military operation and suggest that the methods section of all papers should provide a full description of the data source used, a definition of the method used to determine the population at risk, and a description of the relationship of the data source with the population at risk. In order to enable comparisons between reports, the results section should code clinical diagnoses using the J97 codes as the first level with any further sub-division being based on ICD-10. Clinical activity by speciality or intervention should also follow a standard coding system such as OPCS 4 (18).

\section{References}

1. Roberts MJ, Fox MA, Hamilton-Davies C and Dowson S. The Experience of the Intensive Care Unit in a British Army Field Hospital during the 2003 Gulf Conflict. I R Army Med Corps 2003;149:284-290.

2. Ramalingham T. Extremity Injuries Remain A High Surgical Workload In A Conflict Zone. F R Army Med Corps 2004;150:187-190.

3. Scott JN. Diagnosis And Outcome Of Psychiatric Referrals To The Field Mental Health Team, 202 Field Hospital, OP TELIC. I R Army Med Corps 2005;2:95-100.

4. Grainge C, Heber M. The Role Of The Military Physician In Modern Military Operations: 12 Months Experience In Southern Iraq. 7 Army Med Corps 2005;151:101-104.

5. Ward NJ, Okpala E. Analysis Of 47 Road Traffic Accident Admissions to BMH Shaibah. F R Army Med Corps 2005;151:37-40.

6. Aslam S, Griffiths MF. Eye Casualties During Operation Telic. I R Army Med Corps 2005;151: 34/36.

7. Gurney I. Paediatric Casualties During OPTELIC. f R Army Med Corps 2004;151:270-272.

8. McAllister PD, Blair SP, Philpott S. Op Telic - A Field Mental Health Team In The General Support Medical Setting. F R Army Med Corps; 150:107-112.

9. Owen JP and Macmillan AHM A pilot study of J95 in secondary care in Bosnia. $\mathcal{F} R$ Army Med Corps 1998;144:79-84.

10. Becker GW and Laundy TJ. A lesson not yet learned. F R Army Med Corps 2003;149:274-276.

11. Bricknell MCM and Wright LA. Ex SAIF SERREA II - The field hospital clinical report. $\mathcal{F}$ R Army Med Corps 2004;150:252-255.

12. Jefferson TO and Demichelli J95 - EpiNato based planning parameters for medical support to operations other than war (OOTW). F R Army Med Corps 1998;144:72-78.

13. Allied Medical Support Doctrine. Allied Joint Publication 4.10(A). North Atlantic Treaty Organisation. Brussels. 2005.

14. Allied Joint Medical Support Doctrine AJP 4.10(A) North Atlantic Treaty Organisation, Brussels 2005.

15. Wright LA, Demichelli V, Gillespie WJ and Jefferson TO. Morbidity surveillance in the British Army the first 12 months. I $R$ Army Med Corps 1998;144:11-17. 
16. International Classification of Diseases Version 10. World

Health

Organisation

Geneva.

http://www.who.int/classifications/icd/en/ Accessed 18 Aug 05.

17. Instructions for Authors. F Roy Army Med Corps 2004;150:228-229.
18. Office of Population, Censuses and Surveys Classification of Surgical Operations and Procedures - 4th Revision (OPCS-4) HS Information Authority. http://www.nhsia.nhs.uk/

clinicalcoding/pages/opcs_4.asp accessed 15 Aug 05. 